\title{
地方公共エ事執行プロセスにおける 住民リスクマネジメントと合意形成支援手法
}

\author{
二宮 $\quad$ 仁志 $*^{1} \cdot$ 渡邊 $\quad$ 法美 $^{* 2}$

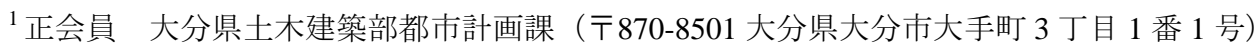 \\ E-mail:ninomiya-hitoshi@pref.oita.lg.jp \\ 2 正会員＼cjkstart高知工科大学マネジメント学部教授（†782-8502 高知県香美市土佐山田町宮ノロ 185） \\ E-mail:watanabe.tsunemi@kochi-tech.ac.jp
}

\begin{abstract}
地方公共工事執行プロセスにおいて，住民に負の影響を及ぼす事象の発生可能性とその対処コス卜を“住民リス ク”と称す。近年，社会基盤整備における合意形成に関わる法改正やガイドラインの整備が進められているが，そ の多くは，事業規模や影響範囲の大きな社会基盤施設の新設・改良を対象としており，比較的小規模の維持補修工 事等に適用することは，住民リスクに関する情報共有・合意形成の観点からも必ずしも適切とは言い難い，住民リ スクは，住民の安全・安心な生活を脅かすばかりでなく，施工業者や発注者にとっても，リスク分担についての事 後的説明や対応一の不満が感情的対立ひいては反対運動や行政批判に発展寸る恐れなど，工事執行に影響を与える 脅威といえ, その適切なマネジメントは喫緊の課題といえる. 本研究は, 工事執行プロセスにおける住民リスクの マネジメント手法について提案することを目的とする，大分県で実施された橋梁補修工事について事例研究し，住 民リスクのマネジメントと合意形成プロセスの現状について明らかにした．また，住民リスク分担にかかる入札・ 契約制度の課題について考察するとともに，住民リスクの適切なマネジメントを通じて，合意形成を支援する実践 的手法について提案を試みた。
\end{abstract}

Key Words : "resident-risk" management, risk communication, consensus building,bidding-contract system

\section{1. はじめに}

地方公共工事執行プロセスにおいて，住民に負の影 響を及ぼす事象の発生可能性とその対処コストを“住民 リスク”之称す。近年，社会基盤整備における合意形成 や市民関与に関わる法改正やガイドラインの整備が次第

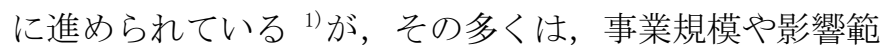
囲の大きな社会基盤施設の新設・改良（以下「新設改良 工事」という）を対象に整備されたものといえ，比較的 小規模の既設構造物の修繯・補修工事（以下「維持補修 工事」という）等に適用することは，住民リスクに関す る情報共有 ・合意形成の観点からも必ずしも適切とは言 い難い，通常の維持補修工事は，用地買収を伴わず，新 設改良工事と比較して, 事業期間 - 工期も短 $<$, 工事目 的物が周辺環境の変化に及ぼす影響が小さく, 着工前の 関与主体の関心も低い場合が少なくない，そのため，工 事説明会等は開催せず，着工直前に施工業者からの工事 案内をもって周知するなど，簡易な手法を採用する場合 が少なくない，一方，実際に工事が始まり，負の影響が
各個人の受忍の限度を超えると不満が感情とともに苦情 となって表出するなど，現場ではその対応に追われてい る，住民リスクは，工事現場周辺の住民の安全・安心な 生活を务か寸ばかりでなく, リスク分担についての事後 的説明や対応への不満が感情的対立ひいては反対運動や 行政批判に発展寸る恐れなど, 発注者や施工業者にとっ ても，工事執行に影響を与える劦威といえ，その適切な マネジメントは喫緊の課題といえる.

本研究は, 工事執行プロセスにおける住民リスクの マネジメント手法について提案することを目的とする. 大分県で実施された橋梁補修工事について事例研究し, 住民リスクのマネジメントと合意形成プロセスの現状 について明らかにした。また，住民リスク分担にかか る入札・契約制度の課題について考察するとともに, 住民リスクの適切なマネジメントを通じて，合意形成 を支援する実践的手法について提案を試みた. 


\section{2. 合意形成プロセスと住民リスク}

\section{（1）プロジェクトサイクルにおける合意形成プロセス}

社会基盤のプロジェクトサイクルにおけるステイクホ ルダー間の意思疎通と社会的合意の形成プロセスを便宜 的に“広義の合意形成プロセス”とし，事業化される前 の構想計画段階，整備段階，供用開始後の維持補修段階 に大別した ${ }^{2)}$ 。その全体像を図ー1 に示す。本稿での “合意形成” は，その各段階での協議を対象とし，特に 工事執行段階における合意形成プロセスに焦点をあてる。

構想計画段階は，社会基盤施設計画について，広く合 意を形成する段階である，都市計画決定等は，この段階 に位置し, 都市計画法の手続きに従い, 対象施設と位置 が定められると, 当該施設の必要性について合意がなさ れたと位置づけられるとともに，以降事業化まで当該土 地利用に一定の制限がかかることとなる。一方，整備段 階に入った後も, 事業の必要性や決定プロセス等につい て疑問を呈する声が絶えない状況を踏まえ, 国土交通省 において, 道路事業における構想段階の合意形成ガイド ラインが示されるなど, 構想段階での対話プロセスの制 度化が推進されてきた。また，構想段階は，施設の必要 性を含め議論がなされる段階であり, 現地での測量・詳 細設計が実施できない。自分の家の前はどうなるのか, 補償額は如何ほどで次の生活に支障はないのか，その時 期はいつかなど，住民が知りたい情報を行政は殆ど持ち 合わせていない場合が少なくない. その状況での行政の 回答は，事業化した後，調査・設計を行う中で説明する に終止せざるを得ない. 数年あるいは数十年後に事業化 され，詳細な内容を知ると「当時そのような説明は無か った，説明があれば合意していない・騙された」といっ た感情的対立に陷る場合もある，当該施設の必要性につ いて住民の合意を得なくては，測量立入も叶わず住民が 知りたい情報を検討・準備することも出来ないなか，そ の情報・説明が不十分なまま，住民も施設の必要性につ いて合意することが出来ない状況に陥るなど，合意形成 プロセスに内包するジレンマについて指摘されている ${ }^{2)}$.

整備段階について，著者（2006）は，道路改良，河川 改修，公園整備など社会基盤整備事業の合意形成プロセ スを調查研究し，図－1（1. ～5. ）のとおり整理してい る ${ }^{2)}$ 。この段階では，当該社会基盤（施設）の「必要 性」については，構想計画段階で合意が得られたものと して議論がはじまる。また，整備段階における合意形成 プロセスは, 概ね 5 つの段階から構成され, そのプロセ

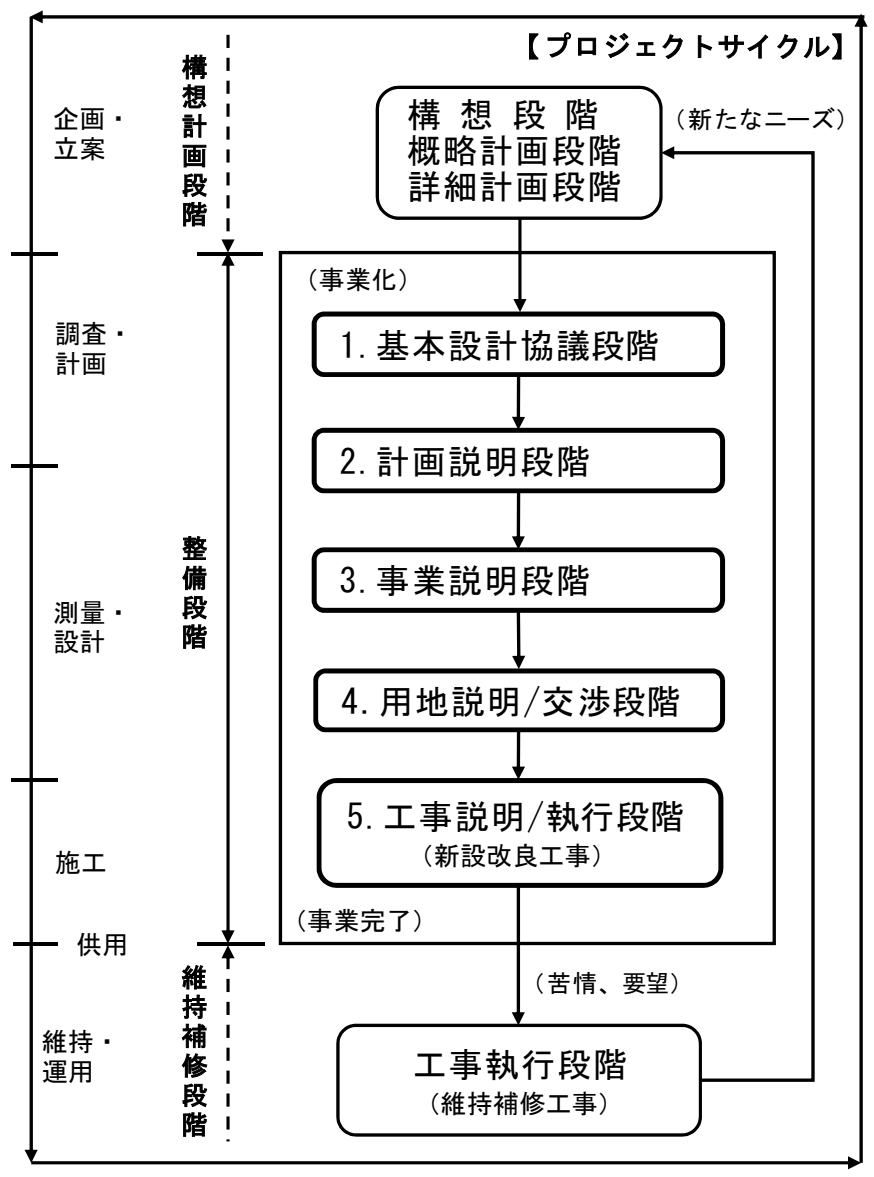

図ー1プロジェクトサイクルにおける合意形成プロセス

スは事業の規模や特性に応じて簡略化されることがあっ ても省略できないなど，そのシステム的特性について明 らかにしている。通常，第 1 段階から第 4 段階まで数年 にわたり協議を重ね，第 5 段階（工事発注）に至る頃に は，住民をはじめ関与主体（「本人の意思に関わらず当 該事業に関与させられる者」をいう） ${ }^{3)} の$ 多くが事業・ 工事概要についてある程度周知している状況にある。こ れは，事業により周辺環境を改変することは避けられず， 自らの生活に負の影響を及ぼす恐れがあるという不安か ら住民各自の関心が高まるためといえる ${ }^{2)}$. 整備段階に おいては，事前に工事概要について知る機会が用意され， 住民にある程度周知された後に発注・着工するという特 徵があるといえる。

維持補修段階においては，道路であれば，陥没・落石 対策など緊急を要する修繥工事から橋梁耐震補強・構造 物の長寿命化など計画的に実施するものまで幅広い，通 常，新たな用地買収を伴わないことから，予め事業損失 が想定される場合を除き，施設管理者の都合でいつでも 着工できる状態にある。長期間にわたる交通規制を伴う など社会的関心の高い工事を除き，工事発注前に説明会 を開催するケースは少なく, 発注後に施工業者が地区代 
表者（地元自治員 - 区長，学校長等）や工事現場周辺住 民に挨拶回りを行うとともに，案内ビラを配布しながら 工事概要（内容・工期，交通規制等）について簡単な説 明を行う場合が多く，整備段階の合意形成プロセスとは 異なっている．維持補修工事は，新設改良工事と異なり， 健全な状態に戻すだけで完工後の生活環境に負の影響を 及ぼす可能性が低いと想定されるため，住民をはじめ関 与主体の関心も低いといえる，特に利用者や住民から損 傷状態が確認できる場合や緊急を要する場合等は，管理 者がそれを速やかに補修するのは当然であり, 説明を聞 く必要もないとの声もある. 従って, 維持補修工事にお いては，事業者（行政）から事前に説明がないまま, 着 工直前に施工業者から簡易な説明・お知らせを受けるに 止まるなど，住民リスクについて知る機会が必ずしも十 分とはいえない場合もあるといった特徵があるといえる.

\section{(2) エ事執行プロセスと住民リスクの分担}

本研究では，工事執行プロセス（着工〜竣工）におい て，住民に負の影響を及ぼす事象の発生可能性とその対 処コストを“住民リスク”と称した。 ここでの「住民」 とは，便宜的に当該工事に伴う受苦圈 ${ }^{4}$ （負の影響を受 ける範囲）に在住する人々をいう。 工事執行に伴う住民 リスクは，主に，事業者（発注者），施工業者（受注 者），住民が分担している，発注者は，当該工事におけ る仮設や対策工など工法選定に責任を有し，設計計上 （各種設計・施工指針，歩掛等に相当部分を依存）・契 約した当該工法に付随するリスクを分担する，受注者は， 工事請負契約の履行に伴うリスクを分担するとともに, 創意工夫（総合評価での提案等）や配慮（作業説明，声 かけ等）など現場での対策を通じてその一部を低減して いるといえる，そして，両者が分担しないリスクは，住 民が自ら対策を講じながら受忍という形で分担を余儀な くされる. 工事騷音であれば，受忍の限度超える騒音の 発生（可能性）に対して, 発注者は低騒音型機械を選 定・設計計上することで当該リスクの一部を分担・低減 し，受注者は施工時間帯の調整等により周辺住民一配慮 するなど履行に伴うリスクを分担・低減し，住民は空を 閉める・エアコンをつけるなどリスク低減しながら我慢

（分担）するなど，三者のリスク分担（コスト負担）が 想定される. 従って, 住民リスクの分担は, 事業者と施 工業者の裁量に委福られ，住民からすると一方的かつ不 透明な決定プロセスと言わざるを得ない，また，住民が 受け取るリスク情報, すなわち, 工事に伴いどのような

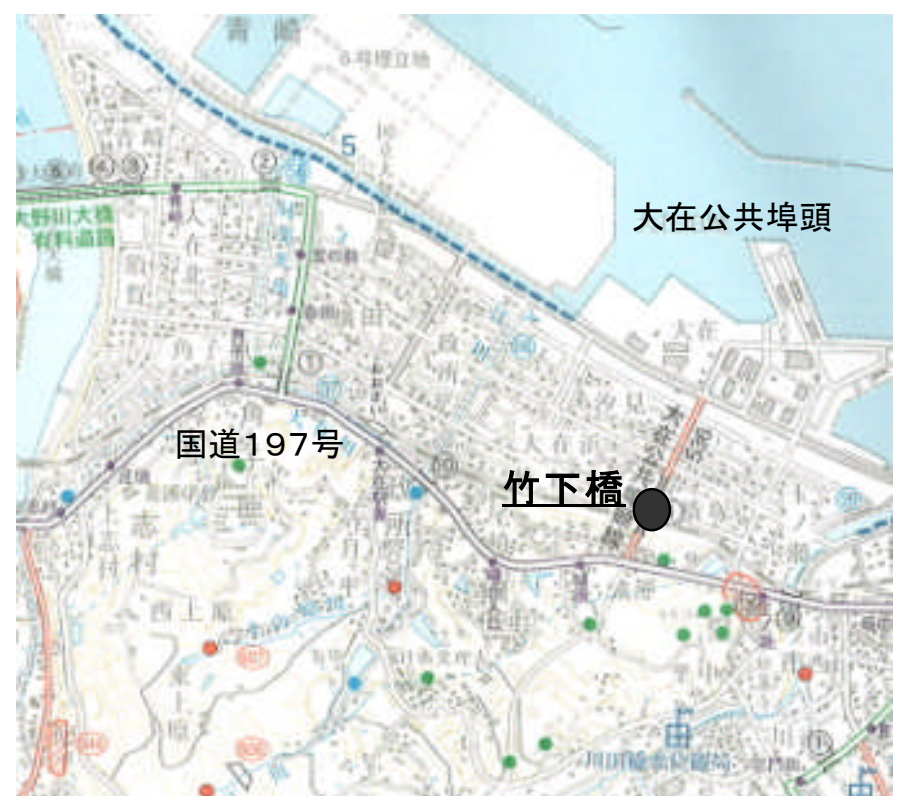

図-2 大在公共埠頭線竹下橋 位置図

負の影響が起こり得るか, その場合, 誰がどういった対 処を行うかについて，どこまで正確かつ丁寧に説明がな されるか等についても施工業者により異なる可能性があ る。そのような不透明なリスク情報下で着工し，負の影 響が住民の受忍の限度を超えた時点で「苦情」という手 段をもって，当該リスクが顕在化し，時に感情的対立を 引き起こすなど，円滑な工事執行において，住民リスク の適切なマネジメントが不可欠であると考えられる。

\section{3. 橋梁補修工事における事例研究}

維持補修工事においては，工事内容や自らが負担す心゙ き住民リスクについて，着工直前まで殆ど知る機会がな く，その説明も施工業者に委初られるなど，新設改良工 事と比較して合意形成プロセスは脆弱といえる，住民と の良好な関係のもと完工した維持補修工事案件について 事例研究し，住民リスクのマネジメントならびに合意形 成支援手法の現状について考察する.

\section{(1) 事業概要}

大分市の一般地方道大在公共埠頭線は，重要港湾大在 公共埠頭と国道 197 号を結ぶ重要な物流ルートであり, 竹下橋は住宅街にかかる鉄道と市道の跨線橋である. そ の位置を図ー2 に示す. 竹下橋は, 8 径間ポストテンシ ヨンT桁橋で架橋から既に 34 年が経過している. 老朽 化による損傷劣化が認められるとともに，耐震補強も必 要な橋梁と位置づけられ，2008 年度から耐震補強なら びに補修工事に着手し，事業期間は 5 年を目標としてい る。ここでは，2009 年度に発注した 3 件の補修工事の 
表 -1 合意形成に繋がる取り組み内容一覧

\begin{tabular}{|c|c|c|c|}
\hline & 項目 & 細目 & 内容 \\
\hline 1 & 粉塵対策 & $\begin{array}{l}\text { 粉塵アタッチメント付き } \\
\text { ディスクサンダー } \\
\text { 集䴤機 } \\
\text { 粉塵吸着シートの使用 }\end{array}$ & $\begin{array}{l}\text { 可能な限り施エヤード内で集塵·処理 } \\
\text { (粉塵を現場から出さないようエ夫) }\end{array}$ \\
\hline 2 & 粉塵対策 & 吹流し·風速計の設置 & $\begin{array}{l}\text { 風向等を勘案し施工時期を管理 } \\
\text { (民家の方へ飛散しないようエ夫) }\end{array}$ \\
\hline 3 & 意思疎通 & $\begin{array}{l}\text { 工事説明用ビラ } \\
\text { 瓦版の配布 } \\
\end{array}$ & $\begin{array}{l}\text { 工事内容の説明及び進捗状況ついて、 } \\
\text { 毎月月初めにお知らせ }\end{array}$ \\
\hline 4 & 簡易補修 & 展望台の修復 & $\begin{array}{l}\text { 老朽化した展望台の屋根支柱を本工事 } \\
\text { で使用した材料により断面修復 } \\
\end{array}$ \\
\hline 5 & 環境美化 & 現場周辺の草刈作業 & 町内会の清掃活動等にも参加 \\
\hline 6 & 防犯活動 & 地域防犯パトロール & 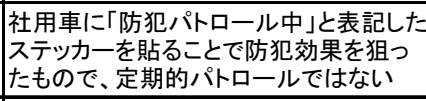 \\
\hline 7 & 応急処置 & 高欄を簡易補修 & $\begin{array}{l}\text { 高欄の固定ボルトが腐食し脱落寸前の } \\
\text { 奖態にあたことを発見し、当面の脱落 } \\
\text { 防止措置を実施 }\end{array}$ \\
\hline 8 & 簡易補修 & 親柱の保護塗装 & $\begin{array}{l}\text { 見栄え·長寿命化の観点から本工事に } \\
\text { 使用した材料により補修 }\end{array}$ \\
\hline
\end{tabular}

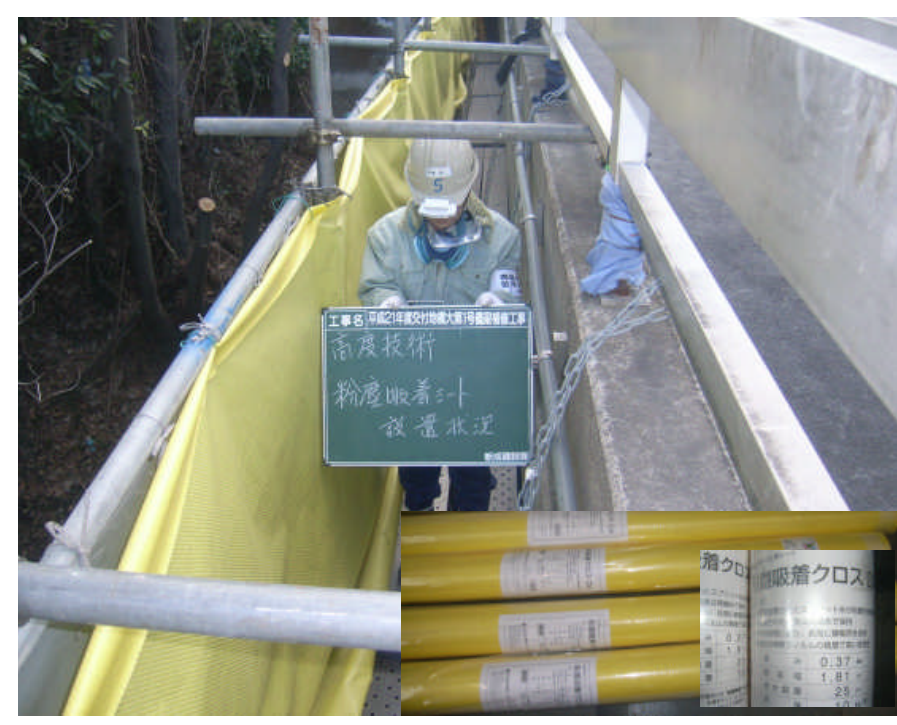

図－3 実施した粉塵対策工の一例

内 1 件を対象とした. 対象工事は, 上部工 2 径間におけ る断面修復工, クラック注入工, 表面保護塗装工で工事 費 65 百万円，契約工期は約 5.5 ヶ月であった.

\section{(2) 工事の特性と住民の関心}

当該工事の主な工種は, コンクリート桁の劣化欠損部 の断面修復工, クラック注入工，表面保護塗装工である. 吊足場（桁高約 $30 \mathrm{~m} ）$ による施工となるため, 足場仮 設・撤去時の仮設材積卸に伴う一時的な車線規制を除き 現道への影響はない，また，塗装ははけ・ローラーによ る人力施工であるため, 建設機械による騒音も殆ど発生 しない. 従って, 当該工事における地域住民の関心は, 塗装工の下地処理（ケレン）時のコンクリート粉の飛散 と塗料の臭気と想定された. 着工迄に，この負の影響に ついて，発注者や施工者がどう考え，工夫・対策しょう としているかを伝え, 理解を得るかが求められた。

\section{(3)施工業者による合意形成にかかる主な取り組み}

当該工事での主な取り組みについて表ー1 に示す. 着 工迄の間に, 工事説明ビラの配布と併せて臨時回覧板で 周辺地区に周知した。 内容は, 工事概要, 工期, 連絡先 を記載した一般的なものだが，可能な限り対面コミュニ ケーションを図りながらの配布に努めた．特に現場隣接 者へは留守でもポストへの投込みは避け，会えるまで何 度も足を運んだ. 着工後は, 工事の進捗状況のお知らせ ビラ（以下「かわら版」という）を近隣住民に配布する とともに，地区の月例回覧板により回覧した。これによ り, 橋面防水工や伸縮継手補修工等の他工事との調整や 天候による工期の遅れ等, 着工案内時の説明内容との相 違をフォローアップした. 2 回目の報告あたりから, 当 初あまり興味を示さなかった（少しでも被害があったら 発注者に言うぞといった空気感が蔓延していた）近隣住 民からも「色々と大変そうですね. がんばってくださ い.」と労いの言葉をかけられるようになるなど住民の 反応に変化が見られ始めた。 また, 着工前に約束した図 -3 に示す粉塵対策工を着実に実施し, 現場から粉塵を 極力出さない努力を日々続け，その状況写真もさり気無 くかわら版に添付した. また, 本工事以外の地域貢献活 動として, 図一4に示す日常管理が行き届かず利用者が 無くなってしまっていた橋梁脇の小さな展望台の簡易補 修（本工事で使用したコンクリート用断面修復材の残等 を活用して老朽化したパーゴラ柱部材を修復）等を行い， かつての地域の数いの場を復活させた。 その他, 現場周 辺の美化活動の一環として, 町内の一斎清掃に参加した り，社用車に「防犯パトロール中」のステッカーを貼る ことで防犯抑止効果を狙う取り組み等, 金銭的制約が厳 しい中でも工夫を続けた. 完工後は, 住民に工事協力に 対するお礼の挨拶周りして現場を後にした。 その結果, 住民から感謝状を頂くまでに至った，施工業者の小さな 努力の積み重ねを地元が評価した証といえる，その過程 には，事前の説明，変更に対する迅速なフォローアップ， 説明内容の実行, 地域へのきめ細やかな配慮など, 施工 プロセスを通じての誠実な行動の積み重ねがあった。

\section{(4) 住民リスクの分担に関する考察}

発注者と施工業者は，着工前に住民の関心など工事に 対する懸念を工種別に抽出し, その対策について協議・ 検討している. 発注者は, 当面, 当初設計計上している 工法の標準的施工に係るリスクを分担し，施工業者は， その履行において必要となる対策についてリスク分担し 

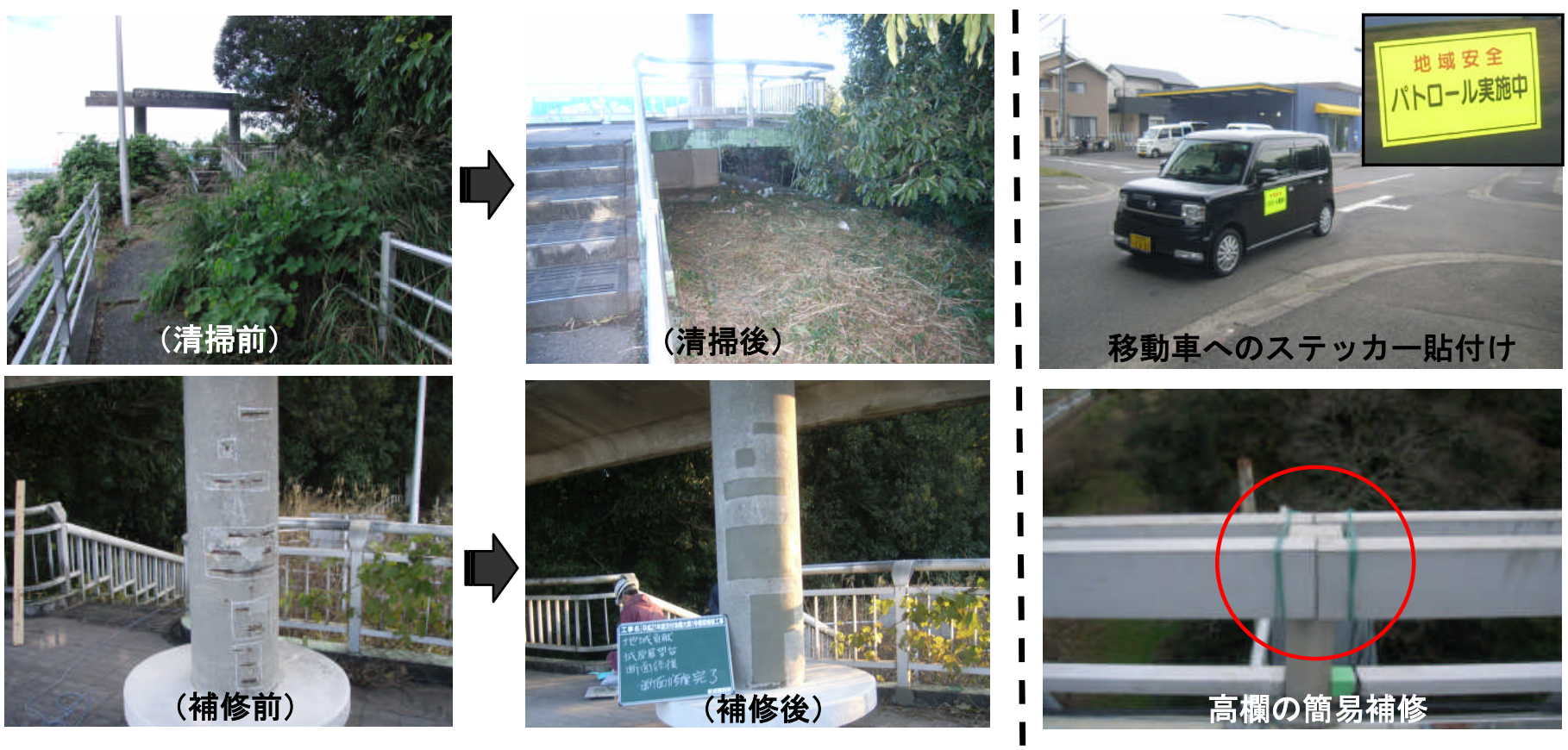

図－4 当該工事における地域貢献活動の一例

ている，粉塵対策としては，飛散防止効果のある防護シ ートは設計計上してあるが，静電気による吸着シート， 集塵機の設置を施工業者の提案により追加している. 施 工中に苦情が出て工事中止となる恐れや工事成績への影 響等を考慮し，コスト負担を伴っても当初から対策を講 じる方が得策という施工業者の判断によるものであった. この判断がなければ，防護シートで防げない粉塵リスク は，住民が分担する結果となっていた可能性が高く，住 民リスクの一部を施工業者が分担・対策工で低減してい る．施工業者あるいは発注者によって，住民リスクの分 担は異なる可能性があるといえる。一方，臭気について は, 材料の変更など抜本的対応は困難であったため, 風 向き等に注意しながら施工するとともに，住民に理解

（受忍）を求め, リスクの分担をお願いした．施工前に は，空を閉めてもらうよう声かけ等を行うなど，住民に リスク低減を促すアドバイスをした。当該工事では，着 工前に住民リスク分担について，発注者と施工者が協議 し，その内容が住民に説明され，住民がそれを受け入れ るという形で，当該工事に対する合意が形成されたと解 釈できる．施工途中においては，住民リスク分担に従い 対策を講じその低減を図るとともに，その状況について， 声かけや瓦版等でお知らせするなど，リスクコミュニケ ーションを継続している.

当該工事は，高度な技術や施工計画の提案を求める工 種はなく, 総合評価方式実績評価タイプが採用されてい る. 一定以上の施工実績を有する数社は, 価格と施工実 績については同点, 実質, 施工上の工夫や町内美化活動
など地域貢献による競争であった，応札者は，住民リス クを他社より多く保有（低減）する工夫を検討せざる得 ない状況にあったといえる. 更に, 受注後も工事中の住 民からの苦情等は工事成績, 次の受注に影響する恐れか ら，住民の声（要望）に答え積極的に対応している。

その結果，住民リスクの分担をめぐり住民から不満の 声や苦情等はなく，良好な関係のもと完工を迎えた，厳 しい受注競争を背景に，住民リスクを施工業者が積極的 に引き受けたことによるものといえる，今後は，住民リ スクの適切な分担について議論するとともに，入札・契 約制度においても，住民リスク分担を明確にする必要が あると考えられる。

\section{（5）住民リスクとコミュニケーション}

住民リスクについて説明し，その一部を分担してもら うには，住民から信頼される必要がある．特に，地区外 の施工業者は “正直者の業者” であるかどうかについて 住民も懐疑的にならざるを得ない，当該工事では，その 克服を目指し，表一 1 に示寸対策を実施している. 苦情 で工事が止まり，みんなが嫌な思いをし，金も気も使い ながら対策を行うのであれば最初から出来る範囲内でや れることをやるほうが結果的にうまくいくと当該工事の 主任技術者は話す。また，作業員全員に自分から声をか けると気持ちいいことを繰り返し伝え, 住民とのコミュ ニケーションを大切にしてきたという。 そして，現場で の取り組みが住民から評価・感謝されると自分も嬉しい し，やりがいにも繋がると胸を張る．地域を思い知恵を しぼる真摰な態度, 挨拶・礼儀を重んじる姿勢が，次第 
に住民から評価され信頼に繋がるとともに，住民の不安 の根底ある住民リスクについて，きめ細やかな説明や情 報提供を継続したことで, 円滑な住民リスクコミュニケ ーションが実現し, 当該工事の合意形成が図られたもの と思われる。

\section{4. 住民リスクマネジメント手法の提案}

3 章の事例研究は, 施工業者や発注者の担当者の勘や 経験を頼りに住民リスクに対処した例といえる．本章で は, 現場担当者の経験知を技術的に支援するため, 効果 的な住民リスクマネジメント手法について提案を試みる.

\section{（1）住民リスクマネジメントの手順}

Pipattanapiwong (2004) は，建設プロジェクトにおけ る多主体間のリスク／不確実性マネジメント手法 MRUMP

(Multi-party Risk and Uncertainly Management Process）を提案している ${ }^{5)}$. 本研究では, MRUMP にお けるマネジメントフローを援用して，(1)リスク因子の抽 出 (identification), (2) リスクの構造化 (structuring)，(3)分析／対策（analysis and response) の 3 ステップとし, また, (3)対策の検討を行 うなかでリスクについて関与主体間で情報共有を図るリ スクコミュニケーションを加えた，その住民リスクマネ ジメントのフローを図ー5に示寸.

\section{(1)リスク因子の抽出 (identification)}

第 1 段階として, 当該工事で想定される住民リスク （R）とその因子（r）を抽出する. 工事に伴う騒音リ スクであれば，工種毎の施工機械騒音や作業騒音等がそ の因子としてあげられる，施工業者においては，当該工 事の主任技術者をはじめ，上司や先輩など，社内での苦 労話や失敗談など過去の工事経験にそのヒントがある. 発注者においては, 事業の経緯, 日頃の苦情・要望, 近 接工事での用地交渉など, 当該地域の情報を保有してい る. 着工前の施工計画協議等を通じて, 住民の心配や懸 念材料, 施工に伴う負の影響など, 施工業者と発注者で リスク情報の交換・共有を図ることは，リスク因子の抽 出に有効といえる.

\section{(2)構造化 (structur ing)}

第 2 段階として, 抽出された複数のリスク因子 $(\mathrm{r} 1, \mathrm{r} 2, \ldots)$ の相互関係について構造化する. 図-5(2) は, リスク因子 $r 1$ と $r 2$ に起因して $r 3$ が発現する等の 関係性を示している，舖装工事であれば，舗装盤破砕工 （r1）と路面切削工（r2）に伴う機械騒音, 積込み・廃 材運搬（r3）に伴う騒音, 更には, 路面切削工（r2）は

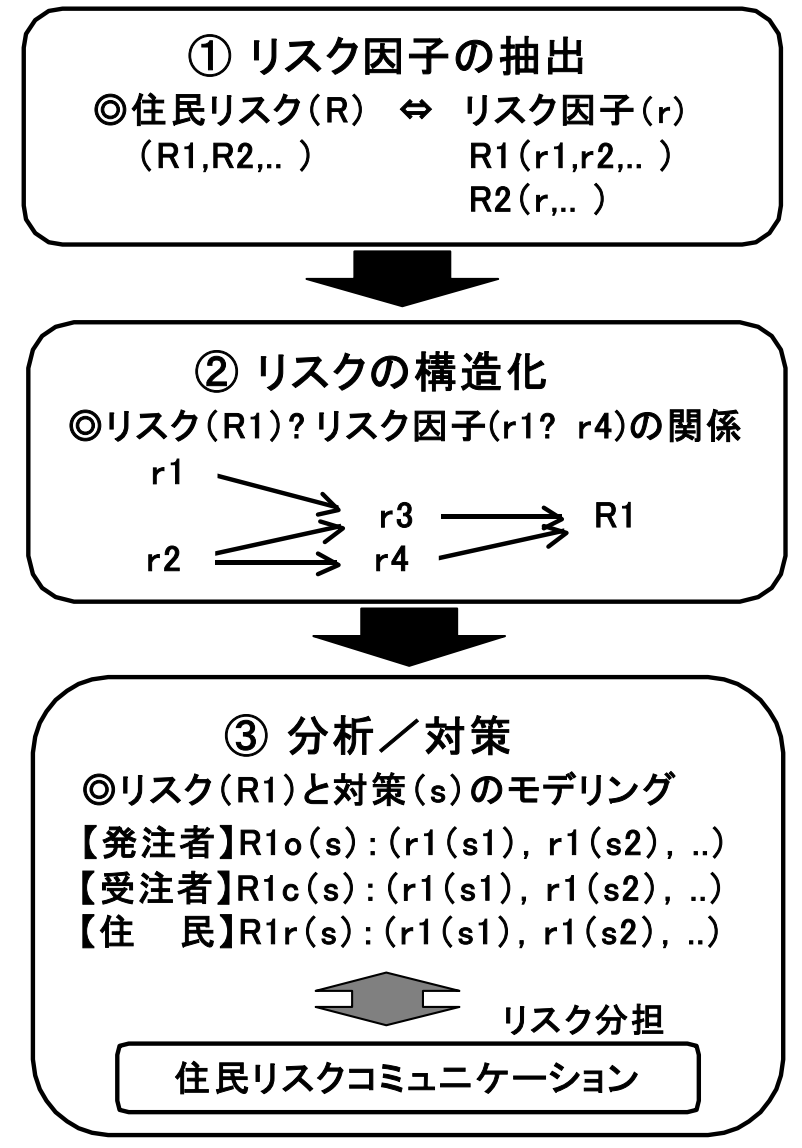

図－5 住民リスクマネジメントのフロー（イメージ）

夜間施工であるため，照明用仮設電源として発動発電機 （r4）騒音が想定されるケース等が構造化される.

\section{(3)分析 /対応 (analysis and response)}

第 3 段階として, リスクと対策の関係を分析するとと もに，関与主体間でリスク分担について意思疎通（以下 「住民リスクコミュニケーション」という）を図る．図 ー5(3)，リスク因子及び関与主体毎に，無対策時 (r1(s1))，対策時（r1(s2)）のリスクについて分析・ 評価することを意味する，分析にあたっては，過去の経 験等からリスク因子ならびに対策毎に発生確率分布を仮 定し，モンテカルロシミュレーションを行うなど，住民 リスクの全体像を確率的に把握することも有効といえる. この分析モデルにより, どの程度の影響がどのくらいの 確率で発生し，想定する対策はどの程度期待できるか等 について定量的に評価・検討することも可能となる.

次にこの分析・評価結果を活用して, 着工までの間に, 発注者と施工者でリスク分担について協議するとともに, 住民の分担するリスクについて工事説明を通じて理解 ・ 協力を促すなど，住民リスクに関する意思疎通を図る必 要がある，着工後もリスク・因子毎についてモニタリン グし，必要に応じて速やかに改善策を検討・実施し，そ 
の経過について住民に情報提供する。この一連の統合的 かつ継続的活動を「住民リスクマネジメント」とした。

\section{（2）住民リスクマネジメントの実践イメージ}

住民リスクマネジメントの実践は，机上での「住民リ スク分析（抽出〜構造化〜分析）」と現場での「リスク コミュケーション（合意形成支援）」に大別される．本 節では, 3 章の工事案件を想定して, 住民リスクマネジ メントの実践イメージについて例示する.

\section{a) 住民リスクの抽出・構造化・分析}

手順(1)（リスク因子の抽出）として, 当該工事で想定 される住民リスク（R）とその因子（r）を抽出する. 当該工事の住民リスクの 1 つに「粉塵」リスク（R1） があり，そのリスク因子（r1）は，塗装下地処理工（ケ レン）であった，当該リスクは，実質，施工業者の対策 に委ねられる部分が多いため，ここでは，施工業者の負 担するリスクについて分析・評価を試みる，評価指標と しては, 工程（遅延）とした.

手順(2)（リスクの構造化）において，抽出されたリス ク（R1）と因子（r1）の関倸性を構造化する，本件で はリスクと因子が共に 1 つと仮定して，ケレン $(\mathrm{r} 1) \rightarrow$ 粉塵（R1）と構造化した。

手順(3)（分析／対応）では, 住民リスクコミュニケー ションの事前準備として，リスクと対策の関係を分析す る. 過去の類似工事や近隣地区での工事経験等を参照し ながら社内あるいは発注者（行政）と情報共有を図るな かで，発生事象や確率について以下の想定がなされたと 仮定する。通常，工事期間中，程度に差はあれ，ほぼ一 度は（90\%程度）苦情が発生し，住民一の説明等に最短 でも 1 日, 通常 3 日, 長びけば 10 日程度を要する.こ の住民一の説明・説得に奔走する状態を s 1 とした. 多 くの場合（70\%程度），納得してもらえず，風向き等を 見ながら施工寸るなど改善策が求められ，5 日程度（標 準偏差 2 日）の工程ロスが生じる. 施工上の工夫により 理解を得ようとする状態を s2 とした。更に，集塵機の 導入など対策工が必要な場合（20\%程度）は，その手配 等に最短 3 日, 通常 5 日, 場合によっては 7 日程度を要 する. 対策工を余儀なくされる状態を s3 とした。 これ らの仮定を表一2 に整理する。ここでは，苦情が発生す ると，まずは，説得を試み（s1），理解が得られない場 合にのみ，施工上の工夫を行い（s2），それでもダメな 場合に対策工を検討する（s3）と仮定し，条件付き確率 により表現した。 また, 工程遅延は, 最低, 最頻, 最大 表－2＼cjkstart住民リスク分析における仮定（一例）

\begin{tabular}{|c|c|c|c|c|c|c|c|c|}
\hline 状態 & \multicolumn{3}{|c|}{ s1 } & \multicolumn{2}{|r|}{ s2 } & \multicolumn{3}{|c|}{ s3 } \\
\hline \multirow{4}{*}{$\begin{array}{c}\text { 発生確率 } \\
\text { P (\%) }\end{array}$} & \multicolumn{3}{|c|}{$P(s 1)$ : 正規分布 } & \multicolumn{2}{|c|}{$P(s 2)$ 正規分布 } & \multicolumn{3}{|c|}{$\mathrm{P}(\mathrm{s} 3)$ : 正規分布 } \\
\hline & 平均 & \multicolumn{2}{|c|}{ 標準偏差 } & 平均 & 標準偏差 & 平均 & \multicolumn{2}{|c|}{ 標準偏差 } \\
\hline & $90 \%$ & \multicolumn{2}{|c|}{$5 \%$} & $70 \%$ & $10 \%$ & $20 \%$ & \multicolumn{2}{|c|}{$15 \%$} \\
\hline & \multicolumn{3}{|c|}{$P(s 1)$} & \multicolumn{2}{|c|}{$P(s 2 \mid s 1)$} & \multicolumn{3}{|c|}{$\mathrm{P}(\mathrm{s} 3 \mid(\mathrm{s} 2 \mid \mathrm{s} 1))$} \\
\hline 対策 & \multicolumn{3}{|c|}{ res1 : 説得 } & \multicolumn{2}{|c|}{ res2: 工夫 } & \multicolumn{3}{|c|}{ res3: 対策工 } \\
\hline \multirow{3}{*}{$\begin{array}{c}\text { 工程遅延 } \\
\text { I (日) }\end{array}$} & \multicolumn{3}{|c|}{ 三角分布 } & \multicolumn{2}{|c|}{ 正規分布 } & \multicolumn{3}{|c|}{ 三角分布 } \\
\hline & 最低 & 最頻 & 最大 & 平均 & 標準偏差 & 最低 & 最頻 & 最大 \\
\hline & 1 & 3 & 10 & 5 & 2 & 5 & 7 & 10 \\
\hline
\end{tabular}

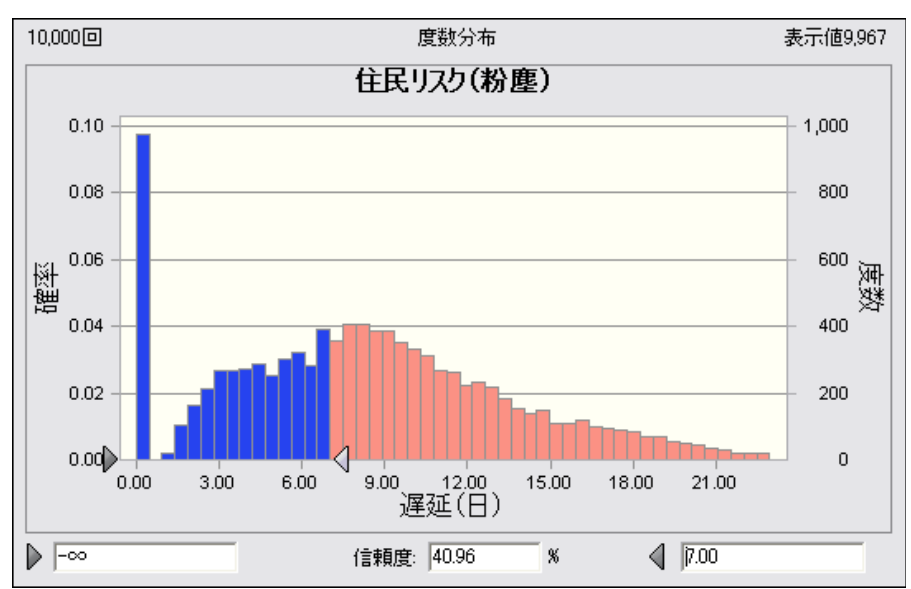

図－6 住民リスク(粉塵)の分析結果（一例）

が想定可能な状態 s1 及び s3 は三角分布で，天候等自然 現象に委敞られる状態 s2 は平均，バラツキを仮定して 正規分布でモデリングし，モンテカルロシミュレーショ ンを行った。 なお, シミュレーターには, Crystal Ball 7 ((株) 構造計画研究所) を用いた。その計算結果を図 -6 に示す. 当該ケースでは, 苦情として発現しない場 合も含め, 7 日以内の遅延で収束する確率は $41 \%$ と低く, 最長では 1 ケ月弱を要し, 概ね 14 日程度の遅延 （86\%）は覚悟する必要があることが分かった。ここで, 仮に日当りの現場管理費が 10 万円（平均）であれば, 140 万円相当とコスト換算できる．対策工（s3）の経費 が 140 万円以下であれば，当初から導入する合理性は有 るなど，対策について検討・評価が可能となる．一方， 住民にとっても，施工業者が着工時から対策工（s3）を 講じることで，s2 よりもリスク（受忍）軽減されると ともに，対策準備や無用な対立に要する期間の短縮に繋 がるなど，より望ましい結果を得られる可能性は高まる と評価できる. 以上のような定量的な分析ツールは, 住 民リスクの適切なマネジメントの一助となると思われる.

\section{b)住民リスクコミュニケーション(合意形成支援)}

住民リスクマネジメントにおいては，住民リスクにつ いて分析・評価するとともに，関与主体間で意思疎通を 
図る合意形成プロセスが特に重要となる，著者の経験の 範囲内において，良好な住民リスクコミュケーションを 通じて, 工事執行プロセスの合意形成を支援する手法に ついて提案する。 その手順を図ー7に示寸。

第 1 フェーズは，事前説明段階である。ここでは，(1) 工事内容，(2)工期，(3)住民リスク分担（生活への負の影 響)，(4)工夫・対策，(5)連絡先（発注者と施工者を併 記）をA 4 サイズ 1 枚にまとめ配布あるいは回覧する. 施工箇所直近の住民には，回覧板やポストへの投げ込み ではなく, 直接手渡しで配布し簡単な説明を添えること とした。これは，後に「聞いていない，そんなビラ入っ ていなかった」というトラブルを未然に回避するためで ある. 自治会長, 学校区長, 校長, 水利組合長等（以下 「地区代表者」という）についても，住民や父兄等から の問合せに応じる必要があることから，上記(1)〜(5)につ いて十分周知する必要があり, 対面コミュニケーション を必須とした。 地区代表者には, 可能な限り, 発注者と 施工者が一緒に挨拶ならびに工事説明に対面で行うこと とした. 工事規模, 住民リスク（影響の程度）, 関係者 数に応じて, 説明会の開催を検討する. 利用者（道路で あれば通行者）に対しては, 現場周辺に予告看板を設置 し事前周知に努めるものとし，長期間の通行止めや規制 等を伴う場合はテレビやラジオなど複数の媒体を検討す る.なお，著者が近年担当した維持・修繥工事案件にお いては，当フェーズは，着工の概ね $2 \sim 3$ 週間前に開始 し，1 週間前迄に完了しておくことを目標としてきた.

第 2 フェーズは，経過報告段階である。この段階は工 事が本格着工し, 騒音・振動・粉塵等, 関与主体に最も 不満や不安の生じやすい時期といえる. 不満や不安が表 出し苦情となる要因の 1 つとして「こんな工事とは聞い ていない! 説明もなかった!」というコミュニケーショ ン不良があげられ，事前説明の内容（第 1 フェーズ）と 現場での対策・対応（第 2 フェーズ）について双方の認 識に相違がある場合が多い，その差を速やかに埋め，不 満や不安を緩和するため，工事の進捗状況等についてお 知らせする, 通称 “かわら版” を地区の月例回覧板と併 せて回覧する等の対応が有効といえる. 特に, 工期の遅 れ，工種追加，それに伴う騒音・振動等の発生について 重点的に説明する必要がある. また, 町内の清掃・美化 活動など地域貢献活動を通じて工事の理解や施工業者へ 信頼が醸成されることで，コミュニケーション不良に起 因する感情的対立は未然に回避されるものと思われる.

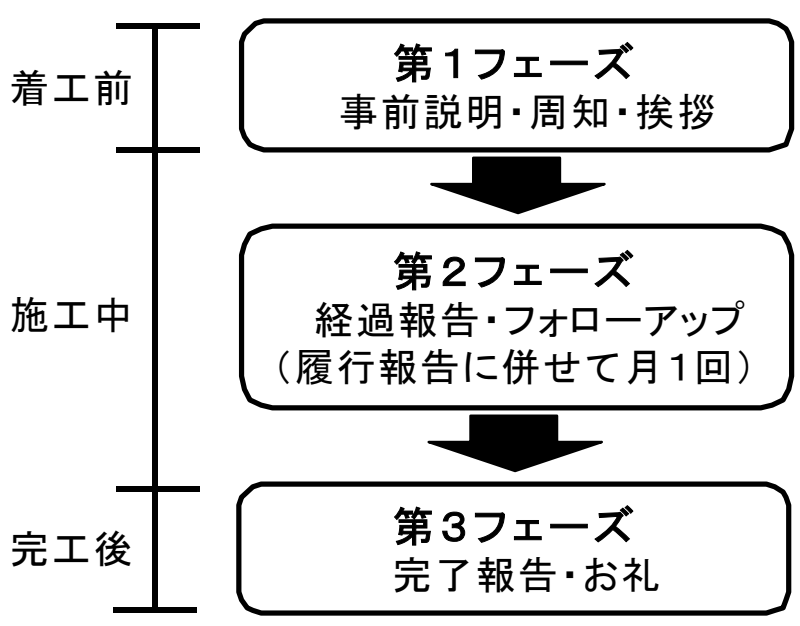

図ー7 住民リスクコミュニケーションの手順

第 3 フェーズは，完了報告段階である．通常，工事が 完了すると現場を引き払うと同時に, 関与主体とのコミ ユケシーョンも途絶え自然消滅してしまう。これでは, 工事に協力してくれた関与主体に感謝の言葉を伝え, 率 直な意見や感想を聞く貴重な機会を逸しているといえる. 住民からの評価に真摰に耳を傾け改善を図るとともに, 地域との良好な関係を構築することは, 次回以降の入札 での競争優位性ひいては企業価值を高めることに繋がる ものと思われる，そこで，完工後は完了報告とお礼を兼 漦て, 第 1 フェーズと同様, 地区関係者に対面コミュニ ケーションによる挨拶と地区住民一の完了報告ビラの配 布を行うこととした。このフェーズでの些細な取り組み は，将来の工事の第 1 フェーズを円滑にする素地づくり に繋がるものと思われる，施工業者にとって馴染みのな い地域でも 3 つのフェーズに相当する活動を真摰に積み 重学ことで，円滑な住民リスクコミュニケーションを 通じた合意形成支援が可能となると期待される.

\section{5. 住民リスクマネジメントにおける課題}

\section{（1）住民リスク分担と入札・契約制度}

公共工事の発注において, 発注者は, 本工事から仮設 工法の選定まで，歩掛表など積算基準に準じて積算する. 国の補助事業（国費充当）の範囲においては，地方自治 体の裁量により積算基準に示される以上の対策は設計計 上できない，3 章の工事案件では，当該地域においても 他の地域と同様，防護シートの設置のみの計上となると ともに，積算段階において，発注者と住民の住民リスク

（粉塵）の分担が決定していたといえる．施工業者は, 本来, 設計計上された工法を忠実に履行することで，住 民リスクの低減に努めるものといえるが，事例研究では， 
住民の分担するリスクの多くを施工業者が分担している. 住民リスクが苦情という形で顕在化することは，そのリ スク分担について, 住民が発注者に対して不満・異議を 唱えていることに他ならならず，施工業者がその全部ま たは一部を分担する合理性はないといえる。一方，地方 公共工事においては, 実績評価タイプなど過去の工事実 績や成績を重視する入札方式が多く採用されるなか，住 民からの「苦情」は, 工事成績に負の影響を与え, 次の 受注を左右する劦威となっている，施工業者は，苦情の 無いあるいは迅速な苦情対応（施工業者による処理）を 余儀なくされ，実質，住民の抱えきれないリスクを請け 負わざる得ない状況にあるといえる. 工事実績を重視す る入札方式は，受注者に片務的かつ過度な住民リスクを 転嫁するシステム的特性を内包しているといえ，当該入 札・契約制度における喫緊の改善点であると考えられる. また, 地域貢献活動は, 現場周辺での清掃・ボランテ イア活動，本工事と関係のない路面補修や交通安全施設 修綡，個人宅の土間の修復など多岐にわたる，その活動 が多い施工業者が地域から歓迎され，良好な関係を構築 できる可能性は高まることは容易に想像できる。また， 技術力での差別化が困難な入札案件が多い中, 次回入札 での優位性確保（劣位性排除）を視野に入れると，地域 貢献活動は必須とせざるを得ない. 受注競争の激化に伴 い過度な地域貢献活動に拍車がかかる中, 本工事の見え ない部分で手を抜き, 見えやすいサービス工事の量的確 保に奔走寸る可能性も否定できない, 更に, 地域貢献活 動の一環として, 個人の要望に応え施工業者が便宜を図 ることは，工事契約上は発注者の関与する域ではなくと も，公共工事執行プロセスを通じて一個人に利益供与す ることは市民から誤解や不公平感を招く恐れもある．当 該契約以外のサービス工事・作業の有無あるいはその質 や量は, 誠実で “正直者 ${ }^{6)}$ ”の業者の選定と一致すると は限らない. 地域貢献活動は, 当該工事における住民リ スクマネジメントの推進を目標とした, 円滑な住民リス クコミュケーションの取り組みとして評価されることが 望ましいと思われる.

\section{（2）住民リスクマネジメントにかかるコスト}

工事執行に伴う住民リスクのマネジメントコストは, 発注者にとっては, 工事費に含まれるものあるいは企業 努力の一環であり，施工業者にとっては，請負工事を円 滑に進めるためのコストの一部との暗黙の了解があると いえる．契約・設計図書に示される工種・工法について，
請負業者は可能な範囲で対策を講じながら施工し，それ でも住民の理解が得られなければ，発注者と協議する形 態が一般的であり，リスク・コストの分担ならびにその 変更プロセスは不透明といえる.

当該コストは「住民リスク低減活動」と「コミュニケ ーション支援活動」に帰着するものに大別できる，住民 リスク低減活動コストは, 設計計上外の追加対策にかか るコストであり，次回入札への影響を考慮して，施工業 者は過度のコスト分担を余儀なくされるケースも少なく ない. 特に, 事業への反対者が多く, 用地交渉が困難で あった事業では，住民からの工事協力が得られにくいな ど，各現場により住民の受忍の限度や，施工業者が負担 を強いられるリスク・コストに差異がある。一方，コミ ユニケーション支援活動コストは，情報提供等を通じて， 住民の分担するリスクについて理解・協力を促すための コストといえる，事業の特性や経緯，住宅密集地か否か など，現場によって，特性（受苦圈）や対象（人数）は 大きく異なり，対話や情報提供にかかるコストは，現行 の諸経費体系においては，施工場所における人口密度等 に応じて，共通仮設費（うち準備費が当該コストに相 当）の補正（市街地補正等）がなされているが，その割 増率では各現場のコミュケーションコストを十分算定で きないケースも懸念される. 近年, 低入札工事が多く, 諸経費率（本工事費に対寸る割合）が圧縮傾向にあるこ とを踏まると，不明瞭なコミュニケーション支援コスト の増大が企業の正当な利益を圧迫し, 健全な経営に支障 をきたす恐れもある，住民リスクを適正に評価・分担・ 設計計上可能な入札・契約制度とマネジメントシステム の構築が求められる.

\section{6. 住民リスクマネジメントに期待される効果}

住民リスクマネジメントは, 苦情処理等に係るコスト を抑え，円滑な工事執行に寄与するとともに，住民との 長期的な信頼関係の構築・醸成が期待される. 特に複数 年にわたる事業では，前回工事・施工業者の評判が次の 工事に影響を及ぼす。初めて現場に入った時，工事に対 する理解や協力の雾囲気・素地が多少なりとも醸成され ていることは，工事を円滑に執行する上で望ましい，更 に現場作業員を含め施工に携わる技術者たちは，一定期 間，当該地域で仕事をすることになり，地域・住民との 関倸性は労務環境に影響を与える要因といえる。朝, 現 場で人とすれ違った時，迷惑そうな顔で無視されるより 
も，笑顔で気軽に声をかけられる方が，この地域のため に少しでも良いものつくろうと知恵をしぼり・汗をかき， 持てる技術力を発揮しようとモチベーションを維持でき る可能性は高いといえる。 その真摰な技術者の姿を住民 が目にすることで, 次第に不安から安心へ, 更には信頼 7)へと繋がり，各地域での良好な関係の醉成は，工事執 行段階のみならず，建設プロジェクトサイクルにかかる リスクを長期的に低減できる可能性を有するものと期待 される。

\section{7. おわりに}

本研究は，工事執行プロセスにおける “住民リスク” とそのマネジメント手法について提案を試みた。

本研究の範囲内で以下のことがいえると考えられる.

（i）“住民リスク”は，合意形成プロセスや入札・ 契約システムなど工事執行プロセスのマネジメント について新たな分析的視点を提供できた.

(ii) 当該マネジメント手法は, 住民リスクの分析・評価 を支援するとともに，リスク分担について議論・検 討する一助となる.

（iii）住民リスクマネジメントを基調（基盤技術）とした コミュニケーション手法では, 工事に伴う住民の不 安・懸念について関与主体間で意思疎通・対処する 実践的プロセスを提供するなど，新たな合意形成支 援の可能性が開かれた.

一方“住民リスク”マネジメント研究は，未だ途につ いたばかりで解決すべき課題は山積している，最後に， 今後の展望と研究課題について述べる. 本研究では, そ の対象を工事執行段階とした。構想段階や整備段階など 建設プロジェクトサイクル全般にわたり住民リスクは潜 在すると思われ，そのマネジメントは喫緊の課題といえ る. 各段階における住民リスク・因子に差異はあれ，そ
のマネジメント手法や方法論に共通点は多く，適用可能 性はあると思われる，そして，住民リスクマネジメント の継続的実践が，長期的スパンでの建設プロジェクトの コストの縮減・適正化に繋がる可能性も期待される，事 例研究等を通じたその適用範囲と有効性の検証は今後の 課題である．また，工事実績を重視する入札方式におい ては，受注者に対する片務的かつ過度な住民リスク転嫁 の危険性について警鐘を鳴らした。関与主体間の適切な 住民リスク分担のあり方やその評価手法の検討，制度改 革の具体的提案も今後の課題である. 住民リスクマネジ メントに関する実務者向けガイドラインなど，合意形成 支援の基盤整備づくりも今後の検討課題である.

\section{参考文献}

1）例えば，国土交通省：公共工事の構想段階における計画策 定プロセスガイドライン，2008.4.

2）二宮仁志：社会基盤整備の合意形成支援手法に関する研究, 東京大学大学院工学系研究科博士論文, 2006 .

3）加藤浩徳：インフラ整備事業における合意形成プロセスへ の市民関与の影響に関する分析, 東京大学大学院工学系研 究科博士論文, 1999 .

4）梶田孝道 : 紛争の社会学「受益圈」と「受苦圈」，「経済 評論」日本評論社，p101-120，1979.

5) Pipattanapiwong, J., Development of Multi-party Risk and Uncertainty Management Process for an Infrastructure Project, Ph. D Thesis, Kochi University of Technology, 2004.

6）渡邊法美，二宮仁志，青山喜代志，野中正明：わが国の地 方公共工事における技術調達に関する一考察, 建設マネジメ ント研究論文集, Vol.15, pp.355-370, 2008.

7）山岸俊男：信頼の構造, 東京大学出版, 1998.

(2012. 5. 14 受付)

\title{
A NEW METHODOLOGY FOR FACILITATING CONSENSUS-BUILDING BASED ON "RESIDENT-RISK" MANAGEMENT SYSTEM IN PUBLIC WORKS
}

\author{
Hitoshi NINOMIYA, Tsunemi WATANABE
}

\begin{abstract}
Recently, it has been improving some legal systems, guidelines, and manuals for public involvement on infrastructure development process, but it is not enough established yet, especially about small project. This paperfocused on "ResidentRisk", it was found some problems about that management andan attempt is made to overcome these problems,to proposea new methodology for facilitating Consensus-buildingbased on "Resident-Risk" Management Systemon execution process in public works.
\end{abstract}

